Soil Science and Agricultural Engineering

http:/www.journals.zu.edu.eg/journalDisplay.aspx?Journalld=1\&queryType=Master

\title{
EFFECT OF SOME ORGANIC MATERIALS ON PRODUCTION OF WHEAT AND FABA BEAN PLANTS GROWN ON TWO DIFFERENT SOILS
}

\author{
Eslam E.I.M. El-Gabrey ${ }^{*}$, I.R. Mohamed, A.M. Helmy and S.M. Shaddad
}

Soil Sci. Dept., Fac. Agric., Zagazig Univ., Egypt

Received: 01/07/2019; Accepted: 30/07/2019

\begin{abstract}
Two pots experiments were conducted under greenhouse conditions to study the effect of five organic soil amendments: Bitumen (Bit), Saw dust (SD), Farm yard manure (FYM), Chicken manure (CM) and Compost (Com) on yield, yield components and chemical components of wheat and faba bean plants grown on two different soils. The organic materials were used at rate of 20 $\mathrm{Mg}$ fad. $^{-1}(2 \%)$. In the first (wheat exp.) and second experiments (faba bean exp.), Ordinary super phosphate at a rate of $13.1 \mathrm{~kg} \mathrm{p}^{-1} \mathrm{fad}^{-1}$ and Potassium sulphate at a rate of $41.5 \mathrm{~kg} \mathrm{k}$ fad $\mathrm{d}^{-1}$ were added to both soils before planting, while ammonium sulphate was added after planting at the rates of 75 and 30 $\mathrm{kg} \mathrm{N}$ fad. ${ }^{-1}$ to wheat and faba bean plants, respectively. The applied nitrogen was divided into three doses, the first dose was applied after planting (15 days) and the second and the third doses were added at tillering and booting stages (after 45 and 70 days, respectively) in the first experiment, while in the second experiment the added nitrogen was divided into two doses, the first dose was applied after planting and the second dose was added at tillering stage (45 days after planting). The results showed that the chicken manure treatment gave the greatest value for each of straw, grains of wheat, seeds of faba bean, roots dry weight, 1000-wheat grain and 1000-faba bean seed weights, biological yield, Harvest Index (\%) and NPK uptake for wheat and faba bean plants grown in both of soil as compared to the other organic treatments. The greatest values of protein content were obtained for wheat and faba bean plants when treated with (CM) and found true in both soils under study. The superiority of used organic amendments effect on all the studied parameters can be arranged in the following descending order: $\mathrm{CM}>\mathrm{FYM}>\mathrm{Com}>\mathrm{Bit}>\mathrm{SD}>$ Control.
\end{abstract}

Key words: Bitumen, saw dust, farm yard manure, chicken manure, compost, sandy clay loam soil, sandy soil.

\section{INTRODUCTION}

Most of Egyptian soils such as the clayey and sandy soils suffer from the lack of available nutrients content; due to increase $\mathrm{pH}$ values and low of organic matter content as well as sandy soils are characterized by their poor physical and chemical properties beside their low capacity to retain water. Efficient use of fertilizers, optimizing crop yield and minimizing environmental pollution is therefore a critical issues. Increasing the ability of plant to take up minerals could have a dramatic impact on both plant and human health (Rus et al., 2005). The Egyptian soils become a necessity to increase agricultural production and to overcome the deficiency in food requirements (El-Kholy et al., 2000; Hassanien et al., 2007; Telep, 2008) wheat and faba bean plants are considered of the most important crops which used as a food for both humans and animals all around the world. The using of natural organic soil amendments are considered as promising practices of improving the nutritive and productive capacity of such soils either directly or indirectly (Chirevnje and Ma, 2002; Chen, 2006). The present work aims at studying the effect of applying different sources of natural organic soil amendments (bitumen, saw dust, farmyard manure, chicken manure, compost) the growth, yield components

\footnotetext{
*Corresponding author: Tel. : +201272890549

E-mail address: maxorloma@yahoo.com
} 
and nutritional status of wheat and faba bean plants grown on two coarse textured soils

\section{MATERIALS AND METHODS}

\section{Materials}

\section{Soil samples}

Two surface $(0-30 \mathrm{~cm})$ soil samples were collected from two different locations in Egypt, Sharkia Governorate to be used in this work. The first sample, represents a sandy clay loam soil from El-Korain county and the second sample, represents a sandy soil from the Farm of Faculty of Agriculture Zagazig University at Elkhattara county. Soil samples were air dried, crushed, sieved through $2 \mathrm{~mm}$ plastic screen, thoroughly mixed and stored in plastic bags for analysis and experimental work. Table 1 shows some physical and chemical characteristics of the investigated soils

Soil analysis was performed according to the methods described by Jackson (1973).

\section{Organic Soil Amendments}

Five types of organic soil amendments were used in this work, which are: bitumen (Bit), saw dust (SD), farm yard manure (FYM), chicken manure (CM) and compost (Com). Some characteristics of the tested amendments are shown in Table 2.

\section{Methods}

\section{Greenhouse experiments}

Two biological experiments were carried out to study the effect of different soil organic amendments (Bitumen, Saw dust, Farm yard manure, Chicken manure, Compost) on plant growth and some macronutrients uptake (N,P and $\mathrm{k}$ ) by plants in two different soils under greenhouse conditions. The organic soil amendments were added and mixed with the soil of each pot before planting. The first experiment was cultivated by wheat (Triticum aestivum, L. Giza 6). Plastic pots of internal dimensions $20 \mathrm{x}$ $20 \mathrm{~cm}$ were filled with $5 \mathrm{~kg}$ of soil samples. The Previously mentioned treatments were mixed with the tested soil before planting and replicated three times. A randomized complete block design was used with three replicates. The organic residues were added at a rate of $2 \%$ (20 $\mathrm{Mg}$ fad. $^{-1}$ ). Fifteen seeds of wheat were seeded per pot. The pots were daily weighed and the soil moisture content was adjusted nearly the field capacity after germination, then plants were thinned to ten plants. Plant with their roots removed after 150 days from sowing gently and washed with tab water till the roots were freed of the soil particles and then washed with distilled water. Plant samples were dried at $70^{\circ}$ $\mathrm{C}$ for 72 hours, then weighed, ground, and analyzed for total nitrogen, phosphorus and potassium. Total $\mathrm{N}, \mathrm{P}$ and $\mathrm{K}$ content were determined according to Jackson (1973) for total N, Watanabe and Olsen (1965) for total P and according to Jackson (1973) for total K. Protein percent \{yield quality in grains was calculated by multiplying N\% x 5.70 (Bishni and Hughes, 1979) and Harvest Index \% [grains $\div($ straw + (grains or seeds $))] \times 100$, also was calculated.

The second experiment was cultivated with faba bean (Vicia faba L. Giza 3), plastic pots of internal dimensions $20 \times 20 \mathrm{~cm}$ which filled with $5 \mathrm{~kg}$ of the soil samples. Three replicates for each of the two indicated soil samples that previously mentioned were used. Organic soil amendments were used as in the first experiment with wheat. Fifteen seeds of faba bean were seeded per pot. The pots were daily weighed and the soil moisture content was adjusted nearly the field capacity. After germination, plants were thinned to three plants. Plants with their roots were removed after 150 days from sowing then, gently washed with tap water till the roots were freed of the soil particles and then washed with distilled water. Plants were divided into shoots and roots. Plant samples were dried at $70^{\circ} \mathrm{C}$ for 72 hours, ground and analyzed for available nitrogen, phosphorus and potassium. At harvest, plants were separated into straw, pods (shell and seeds) and roots. Yield and yield components were recorded. Protein content \{yield quality in seeds was calculated by multiplying N\% x 6.25 (Bishni and Hughes, 1979) and Harvest Index [seeds $\div$ (straw + pods $)$ ] x 100, also calculated.

Methods of analysis used in this study were described according to Chapman and Pratt (1961), Black et al. (1965) and Jackson (1972). 
Table 1. Some Physical and chemical characteristics of the investigated soils

\begin{tabular}{|c|c|c|}
\hline Characteristic & El-Korain & El-Khattara \\
\hline$\overline{\text { Sand }(\%)}$ & 67.10 & 91.87 \\
\hline Silt (\%) & 3.40 & 6.03 \\
\hline Clay (\%) & 29.50 & 2.10 \\
\hline Textural class & Sandy clay loam & Sandy \\
\hline Bulk density, $\mathrm{Kg} \mathrm{m}^{-3}$ & 1.26 & 1.60 \\
\hline Total porosity (\%) & 43.39 & 26.98 \\
\hline MWHC (\%) & 42.05 & 16.60 \\
\hline Water in air dry soil (\%) & 3.49 & 0.47 \\
\hline Expansion (\%) & 14.78 & 0 \\
\hline pH & 8.13 & 7.67 \\
\hline $\mathrm{EC} \mathrm{dSm}^{-1}$ & 0.77 & 0.39 \\
\hline $\mathrm{CaCO}_{3}\left(\mathrm{~g} \mathrm{~kg}^{-1}\right)$ & 16.00 & 5.00 \\
\hline OM $\left(\mathrm{g} \mathrm{kg}^{-1}\right)$ & 12.70 & 4.80 \\
\hline
\end{tabular}

*MWHC: Maximum water holding capacity

pH: soil: water suspension $(1: 1)$

EC: soil paste extract

Table 2. Some characteristics of organic soil amendments

\begin{tabular}{|c|c|c|c|c|c|}
\hline \multirow[t]{2}{*}{ Property } & \multicolumn{5}{|c|}{ Organic soil amendment } \\
\hline & $\begin{array}{c}\text { Bitumen } \\
\text { (Bit) }\end{array}$ & $\begin{array}{l}\text { Saw dust } \\
\text { (SD) }\end{array}$ & $\begin{array}{c}\text { Farmyard } \\
\text { manure (FYM) }\end{array}$ & $\begin{array}{c}\text { Chicken } \\
\text { manure }(\mathrm{Cm})\end{array}$ & $\begin{array}{c}\text { Compost } \\
\text { (Com) }\end{array}$ \\
\hline$\overline{\mathrm{pH}}$ & $\overline{--}$ & 7.50 & 8.20 & 7.10 & 4.50 \\
\hline $\mathrm{ECdSm}^{-1}$ & -- & Traces & 7.10 & 7.51 & 7.21 \\
\hline OC & -- & 87.4 & 23.2 & 14.9 & 4.5 \\
\hline $\mathrm{C} / \mathrm{N}$ ratio & -- & 583 & 13.6 & 10.2 & 32.2 \\
\hline Total N(\%) & -- & 0.15 & 1.71 & 1.46 & 0.14 \\
\hline \multicolumn{6}{|l|}{ Macronutrients ( $\mathrm{mg} \mathrm{kg}^{-1}$ ) } \\
\hline Available-N & -- & Traces & 1.0 & 46.6 & 12.3 \\
\hline Available-P & -- & Traces & 3.4 & 19.0 & 6.51 \\
\hline Available-K & -- & Traces & 53.3 & 51.2 & 29.1 \\
\hline Total porosity (\%) & 30.65 & 78.57 & 35.35 & 50.58 & 61.64 \\
\hline MWHC (\%) & 2.76 & 534.2 & 95.71 & 228.5 & 83.71 \\
\hline Water in air dried manure $(\%)$ & 355.66 & 12.68 & 9.39 & 22.82 & 10.63 \\
\hline
\end{tabular}




\section{Mineral fertilizers}

Ammonium sulphate (205 $\mathrm{g} \mathrm{N} \mathrm{kg}^{-1}$ ) as nitrogen source at rate of $75 \mathrm{~kg} \mathrm{~N}$ fad. ${ }^{-1}$ for wheat plant was divided into three doses, the first dose was applied after planting (15 days) and the second and the third doses were added at tillering and booting stages, respectively and $13.1 \mathrm{~kg} \mathrm{p} \mathrm{fad} .^{-1}$ for faba bean plant was divided into two doses, the first dose was applied after planting and the second dose was added at tillering stage, ordinary super phosphate $(6.76 \mathrm{~g}$ $\left.\mathrm{P} \mathrm{kg}^{-1}\right)$ as phosphorus sources a rate of $13.1 \mathrm{~kg} \mathrm{p}$ fad. $^{-1}$ for both plants and potassium sulphate $\left(400 \mathrm{~g} \mathrm{~K} \mathrm{~kg}^{-1}\right)$ as potassium source at a rate of $41.5 \mathrm{~kg} \mathrm{k} \mathrm{fad}^{-1}$ for both plants were used as a soil application.

\section{RESULTS AND DISCUSSION}

\section{Effect of Tested Organic Amendments on Yield of Wheat and Faba Bean Plants, Grown on the Two Investigated Soils}

The results given in Table 3 show the effect of organic soil amendments on straw, grain and root dry weights $\left(\mathrm{g} \mathrm{pot}^{-1}\right)$ of wheat as well as straw, seed and root for faba bean plants grown on sandy clay loam soil and sandy soil.

Results in Table 3 show that all the treatments in both soils significantly increased the straw, grains, seeds and roots dry weight compared to the control treatment. This may be explained on the fact that the applications of organic soil amendments improve hydro physical, chemical and biological properties of the sandy clay loam and sandy soils as well as organic manures being a storehouse for essential plant nutrients. These findings were in well agreement with those obtained with Basyouny (2002), Basyouny et al. (2003), Merwad (2009) and (2013).

Irrespective of the control treatments, the straw dry weight values ranged between 7.17 and $13.5 \mathrm{~g} \mathrm{pot}^{-1}$ for wheat and between 8.84 and $18.5 \mathrm{~g} \mathrm{pot}^{-1}$ for faba bean in sandy clay loam soil and between 5.35 and $8.93 \mathrm{~g} \mathrm{pot}^{-1}$ for wheat and between 7.60 and $16.7 \mathrm{~g} \mathrm{pot}^{-1}$ for faba bean in sandy soil. The lowest straw dry weight values were observed with the treatment of Saw dust
(SD), while the greatest ones were obtained under the application of chicken manure (CM) in both tested soils. The values of grains dry weight ranged between 7.05 and $11.3 \mathrm{~g} \mathrm{pot}^{-1}$ for wheat and between 5.16 and $10.5 \mathrm{~g}$ seeds pot $^{-1}$ for faba bean in sandy clay loam soil and between 5.68 and $9.56 \mathrm{~g} \mathrm{pot}^{-1}$ for wheat grains and between 4.80 and $6.19 \mathrm{~g} \mathrm{pot}^{-1}$ for faba bean seeds in sandy soil. For the two tested plants grown in both soils, the lowest grains and seeds dry weight values were found with the treatment of saw dust (SD), while the highest ones were recorded with the treatment of chicken manure (CM). The roots dry weight values ranged between 5.09 and $6.03 \mathrm{~g} \mathrm{pot}^{-1}$ for wheat plant and between 4.80 and $6.22 \mathrm{~g} \mathrm{pot}^{-1}$ for faba bean plant in a sandy clay loam soil and between 3.69 and $4.84 \mathrm{~g} \mathrm{pot}^{-1}$ for wheat and between 4.25 and $4.99 \mathrm{~g} \mathrm{pot}^{-1}$ for faba bean in a sandy soil. The lowest roots dry weight values were obtained under addition saw dust (SD) for the two tested plants in both soils, while the greatest ones were observed with the treatments of chicken manure (CM) when applied to the two cultivated soils with both plants under study.

In general, the effect of organic soil amendments on the dry weights of straw, grains, seeds and roots of wheat and faba bean plants grown in both soils can be arranged for different treatments in the following descending order: $(\mathrm{CM})>(\mathrm{FYM})>($ Com $)>($ Bit $)>($ SD $)>($ Control $)$.

These results may be due to one or all of the following possibilities:

1. The nutrients content in chicken manure (CM) was relatively higher if compared to the other organic residues under study (Table 2), these results are in agreement with those obtained by El-Kholy et al. (2000), Basyouny (2002), Merwad (2009), Awad et al. (2013), El-Sayed (2017) and El-Tahawey et al. (2017).

2. The variation in $\mathrm{C} / \mathrm{N}$ ratio, the chemical composition (Table 2) and decay rate of the organic manures under study. These findings are in accordance with those obtained by Merwad (2009), Awad et al. (2013), ElTahawy et al. (2017) and El-Sayed (2017). 
Table 3. Effect of organic soil amendments on wheat and faba bean dry matter yield ( $\left.\mathrm{g} \mathrm{pot}^{-1}\right)$ grown on two different soils

\begin{tabular}{ccccccc}
\hline Treatment & \multicolumn{5}{c}{ Sandy clay loam soil } & \multicolumn{3}{c}{ Sandy soil } \\
\cline { 2 - 6 } & Straw & Grains & Roots & Straw & Grains & Roots \\
\hline \multirow{2}{*}{ Control } & 6.23 & 5.87 & 4.55 & 5.24 & 5.43 & 3.49 \\
Bit & 7.28 & 7.14 & 5.11 & 5.49 & 6.22 & 3.84 \\
SD & 7.17 & 7.05 & 5.09 & 5.35 & 5.68 & 3.69 \\
FYM & 8.88 & 7.50 & 5.87 & 6.52 & 7.23 & 4.75 \\
CM & 13.5 & 11.3 & 6.03 & 8.93 & 9.56 & 4.84 \\
Com & 7.99 & 7.30 & 5.64 & 6.05 & 6.93 & 4.20 \\
LSD 0.05 & 0.0971 & 0.1373 & 0.6330 & 0.0506 & 0.0404 & 0.1638 \\
& & \multicolumn{5}{c}{ Wheat } \\
& Straw & Seeds & Roots & Straw & Seeds & Roots \\
Control & 8.06 & 4.58 & 4.43 & 7.29 & 4.09 & 4.11 \\
Bit & 10.6 & 5.83 & 5.75 & 8.96 & 4.98 & 4.31 \\
SD & 8.84 & 5.16 & 4.80 & 7.60 & 4.80 & 4.25 \\
FYM & 12.8 & 6.50 & 5.93 & 11.9 & 5.46 & 4.85 \\
CM & 18.5 & 10.5 & 6.22 & 16.7 & 6.19 & 4.99 \\
Com & 12.5 & 6.39 & 5.42 & 11.3 & 5.01 & 4.63 \\
LSD 0.05 & 0.5783 & 0.6371 & 0.1016 & 0.0967 & 0.1326 & 0.0967 \\
\hline Bit: Bitumen & SD: Saw dust & FYM :Farm yard manure & CM: Chicken manure & Com:Compost
\end{tabular}

3. The values of accumulated $\mathrm{CO}_{2}$ gas due to decay of chicken manure were greater than those from decomposition of the other organic manures as well as the dissolving ability of some organic acids, especially amino acids as a result of decay of chicken manure lead to solubilizing of insoluble nutrients compounds in soils As reported by Salem et al. (2004), Hassan et al. (2002), Merwad (2009), Awad et al. (2013) and El-Tahawy et al. (2017).

4. Chicken manure may increase the ability of cellular membrane of plant roots to absorb nutrients compared to the other organic residues as a result of the reduction in ratios of $\mathrm{Na} / \mathrm{Ca}$ and $\mathrm{Na} / \mathrm{K}$ in soil solution and improve water -soil-plant relationship.
In general, the favorable effect of various organic soil amendments on straw, seeds and roots yield of wheat and faba bean plants was more pronounced in the sandy clay loam than in the sandy soil, which may be related to the high ammonia loss by volatilization. Those findings as in accordance with those obtained by Ali (2017) and El-Sayed (2017).

Effect of Tested Organic Amendments on Biological Yield and the Wheat 1000grains and Faba bean 1000-seeds Dry Weight Grown on the Investigated Soils

The results given in Table 4 show the effect of organic soil amendments on the wheat 1000grain weight and faba bean 1000-seed weight and biological yield $\left(\mathrm{g} \mathrm{pot}^{-1}\right)$ grown on sandy clay loam soil and sandy soil. 
Table 4. Effect of organic soil amendments on wheat 1000-grain weight and faba bean 1000seed weight as well as biological yield $\left(\mathrm{g} \mathrm{pot}^{-1}\right)$.

\begin{tabular}{|c|c|c|c|c|}
\hline \multirow[t]{2}{*}{ Treatment } & \multicolumn{2}{|c|}{ Sandy clay loam soil } & \multicolumn{2}{|c|}{ Sandy soil } \\
\hline & 1000-Grain weight & Biological yield & 1000-Grain weight & Biological yield \\
\hline \multicolumn{5}{|c|}{ Wheat } \\
\hline Control & 101 & 16.7 & 48.0 & 14.2 \\
\hline Bit & 349 & 19.5 & 75.8 & 15.6 \\
\hline SD & 320 & 19.3 & 74.3 & 14.7 \\
\hline FYM & 433 & 22.3 & 98.0 & 18.5 \\
\hline $\mathbf{C M}$ & 481 & 30.8 & 116 & 23.3 \\
\hline Com & 361 & 20.9 & 77.5 & 17.2 \\
\hline LSD 0.05 & 2.1575 & 0.0623 & 2.7853 & 0.0917 \\
\hline \multicolumn{5}{|c|}{ Faba bean } \\
\hline & 1000-Seed weight & Biological yield & 1000-Seed weight & Biological yield \\
\hline Control & 436 & 17.1 & 306 & 15.5 \\
\hline Bit & 737 & 22.2 & 433 & 18.3 \\
\hline SD & 725 & 18.8 & 420 & 16.7 \\
\hline FYM & 870 & 25.2 & 476 & 22.2 \\
\hline CM & 970 & 35.2 & 480 & 27.9 \\
\hline Com & 819 & 24.3 & 450 & 20.9 \\
\hline LSD 0.05 & 6.8040 & 6.2281 & 6.5318 & 6.1359 \\
\hline
\end{tabular}

See footnote of Table 3 .

Results in Table 4 show that all the treatments in both soils significantly increased the 1000-grain and 1000-seed dry weight compared to the control treatment. These findings are in agreement with those obtained by Basyouny (2001), El-Zahar et al. (2007) and Abdel All et al. (2003).

Irrespective of the control treatment, the 1000 -grain and 1000 -seed dry weight values ranged between 320 and $481\left(\mathrm{~g} \mathrm{pot}^{-1}\right)$ for wheat and between 725 and $970\left(\mathrm{~g} \mathrm{pot}^{-1}\right)$ for faba bean, in sandy clay loam soil and between 74.3 and $116\left(\mathrm{~g} \mathrm{pot}^{-1}\right)$ for wheat and between 420 and 480 $\left(\mathrm{g} \mathrm{pot}^{-1}\right)$ for faba bean, in sandy soil. The lowest 1000-grain and seed dry weight values were observed with the treatment of saw dust (SD), while the greatest ones was obtained due to the application treatment of chicken manure (CM) for both tested soils under study. The values of biological yield ranged between 19.3 and 30.8, g pot $^{-1}$ for wheat and between 18.8 and 35.2, $\mathrm{g} \mathrm{pot}^{-1}$ for faba bean in sandy clay loam soil while, in sandy soil it varied between 14.7 and $23.3 \mathrm{~g} \mathrm{pot}^{-1}$ for wheat and between 16.7 and $27.9 \mathrm{~g} \mathrm{pot}^{-1}$ for faba bean. The lowest 1000-grain weight and 1000 -seed weight were obtained owing to the (SD) treatment, while the highest ones were recorded with the treatment of $(\mathrm{CM})$ and that found true in both soils under study.

In general, the effect of organic amendments on the wheat 1000-grain weight, faba bean 1000 -seed weight and biological yield in both soils can be arranged for different treatments in the following descending order: $(\mathrm{CM})>(\mathrm{FYM})$ $>($ Com $)>($ Bit $)>($ SD $)>($ Control $)$.

\section{Effect of Tested Organic Amendments on Nitrogen Uptake of Wheat and Faba Bean Plants Grown on the Investigated Soils}

The results presented in Table 5 show the effect of organic amendments on straw, grains, seeds and roots nitrogen uptake of wheat and faba bean plants grown on sandy clay loam soil and sandy soil.

Results in Table 5 show that all the treatments in both soils significantly increased the straw, grains, seeds and roots nitrogen uptake 
Table 5. Effect of organic soil amendments on nitrogen uptake $\left(\mathrm{mg} \mathrm{pot}^{-1}\right)$ by wheat and faba bean plants grown on two different soils

\begin{tabular}{ccccccc}
\hline Treatment & \multicolumn{3}{c}{ Sandy clay loam soil } & \multicolumn{3}{c}{ Sandy soil } \\
\hline & Straw & Grains & Roots & Straw & Grains & Roots \\
\hline Control & 32 & 73 & Wheat & & & \\
Bit & 38 & 79 & 35 & 18 & 35 & 15 \\
SD & 37 & 77 & 31 & 29 & 62 & 26 \\
Fym & 45 & 83 & 40 & 33 & 58 & 25 \\
CM & 47 & 88 & 43 & 35 & 72 & 31 \\
Com & 42 & 80 & 39 & 31 & 68 & 33 \\
LSD 0.05 & 0.6125 & 0.6847 & 0.6228 & 0.6354 & 0.6258 & 0.6254 \\
& & & Faba bean & & & \\
& Straw & Seeds & Roots & Straw & Seeds & Roots \\
Control & 45 & 65 & 44 & 32 & 41 & 40 \\
Bit & 51 & 78 & 53 & 41 & 65 & 49 \\
SD & 50 & 75 & 51 & 39 & 62 & 45 \\
Fym & 55 & 84 & 58 & 46 & 71 & 52 \\
CM & 59 & 88 & 60 & 50 & 80 & 54 \\
Com & 53 & 80 & 55 & 43 & 69 & 50 \\
LSD 0.05 & 0.6847 & 0.6854 & 0.6328 & 0.6985 & 0.6475 & 0.6217 \\
\hline
\end{tabular}

compared to the control treatment. These findings are in agreement with those obtained by Taha (2000), Rochette et al. (2006) and Shnsuke (2004).

Irrespective of the control treatment, the straw nitrogen uptake values ranged between 37 and $47 \mathrm{mg} \mathrm{pot}^{-1}$ for wheat plants and varied between 50 and $59 \mathrm{mg} \mathrm{pot}^{-1}$ for faba bean plants in sandy clay loam soil while in sandy soil varied between 26 and $35 \mathrm{mg} \mathrm{pot}^{-1}$ for wheat plants and between 39 and $50 \mathrm{mg} \mathrm{pot}^{-1}$ for faba bean. The lowest straw nitrogen uptake value was observed with the treatment of saw dust (SD), while the greatest one was obtained under the application treatment of chicken manure (CM) for the two tested soils under study. The values of wheat grains nitrogen uptake ranged between 77 and $88 \mathrm{mg} \mathrm{pot}^{-1}$ and between 75 and $88 \mathrm{mg} \mathrm{pot}^{-1}$ for faba bean seeds in sandy clay loam soil while in sandy soil it varied between, 58 and $75 \mathrm{mg} \mathrm{pot}^{-1}$ for wheat grains and between 62 and $80 \mathrm{mg} \mathrm{pot}^{-1}$ for faba bean seeds. For the two tested plants grown in both soils, the lowest grains and seeds nitrogen uptake values were found when plants treated with saw dust (SD), while the highest ones were recorded with the treatment of chicken manure (CM). The roots nitrogen uptake values ranged between 31 and $43 \mathrm{mg}$ pot $^{-1}$ for wheat and between 51 and 60 $\mathrm{mg} \operatorname{pot}^{-1}$ for faba bean in a sandy clay loam soil and between 25 and $33 \mathrm{mg}^{-1}$ pot $^{-1}$ for wheat and between 45 and $54 \mathrm{mg} \mathrm{pot}^{-1}$ for faba bean in the sandy soil. The lowest roots nitrogen uptake value was obtained under addition treatment of saw dust (SD) for the two tested plants in both soils, while the greatest ones were observed with the treatment of chicken manure $(\mathrm{CM})$ and found true for the two soils under study.

In general, the effect of organic soil amendments on the nitrogen uptake of straw, grains and roots of wheat and straw, seeds and roots faba bean plants grown in both soils can be arranged for different treatments in the following descending order: $(\mathrm{CM})>(\mathrm{FYM})>$ $(\mathrm{Com})>($ Bit $)>(\mathrm{SD})>($ Control $)$.

\section{Effect of Tested Organic Amendments on Phosphorus Uptake of Wheat and Faba Bean Plants Grown on the Investigated Soils}

The results given in Table 6 show the effect of organic amendments on straw, grains of wheat, seeds of faba bean and roots phosphorus uptake grown on sandy clay loam soil and sandy soil. 
Table 6. Effect of organic soil amendments on phosphorus uptake $\left(\mathrm{mg} \mathrm{pot}^{-1}\right)$ by wheat and faba bean plants grown on two different soils

\begin{tabular}{ccccccc}
\hline Treatment & \multicolumn{2}{c}{ Sandy clay loam soil } & & Sandy soil \\
& Straw & Grains & Roots & Straw & Grains & Roots \\
\hline & & & Wheat & & & \\
Control & 0.46 & 4.70 & 1.23 & 0.24 & 1.40 & 0.08 \\
Bit & 0.64 & 7.10 & 1.34 & 0.34 & 4.30 & 0.50 \\
SD & 0.58 & 7.40 & 1.31 & 0.31 & 3.50 & 0.43 \\
FYM & 1.17 & 9.80 & 1.38 & 0.45 & 5.40 & 0.91 \\
CM & 1.50 & 9.92 & 2.16 & 0.49 & 5.70 & 1.04 \\
Com & 0.79 & 8.50 & 1.36 & 0.40 & 5.20 & 0.86 \\
LSD 0.05 & 0.3254 & 0.3958 & 0.3547 & 0.3854 & 0.3278 & 0.3652 \\
& & & Faba bean & & & \\
& Straw & Seeds & Roots & Straw & Seeds & Roots \\
Control & 1.47 & 8.99 & 1.21 & 1.16 & 5.40 & 0.20 \\
Bit & 2.73 & 10.7 & 1.68 & 1.67 & 7.30 & 0.90 \\
SD & 2.58 & 11.0 & 1.75 & 1.61 & 6.90 & 0.80 \\
FYM & 2.87 & 12.9 & 2.20 & 1.96 & 8.40 & 1.40 \\
CM & 3.75 & 13.0 & 3.50 & 2.20 & 8.50 & 1.60 \\
Com & 2.85 & 11.4 & 1.81 & 1.84 & 7.50 & 1.30 \\
LSD 0.05 & 0.3254 & 0.3637 & 0.3054 & 0.3874 & 0.3857 & 0.3254 \\
\hline
\end{tabular}

See footnote of Table 3 .

Results in Table 6 show that all the treatments in both soils significantly increased the straw, seeds and roots phosphorus uptake compared to the control treatment. These findings are in well agreement with those obtained by Cooperband et al. (2002), Bar-Tal et al. (2004), Courtney and Mullen (2007), Gil et al. (2007), Zhang et al. (2009) and Zhuo et al. (2009).

Irrespective of the control treatments, the straw phosphorus uptake values ranged between 0.58 and $1.5 \mathrm{mg} \mathrm{pot}^{-1}$ for wheat and between 2.58 and $3.75 \mathrm{mg} \mathrm{pot}^{-1}$ for faba bean in sandy clay loam soil and between 0.31 and $0.49 \mathrm{mg}$ pot $^{-1}$ for wheat and between 1.61 and $2.20 \mathrm{mg}$ pot $^{-1}$ for faba bean in sandy soil. The lowest Phosphorus uptake values were observed with the treatment of saw dust (SD), while the greatest ones were obtained under the application of the treatment of chicken manure $(\mathrm{CM})$ to the two investigated soils.

The values of grains of wheat and seeds of faba bean phosphorus uptake ranged between 7.10 and $9.92 \mathrm{mg} \mathrm{pot}^{-1}$ for wheat grains and between 10.7 and $13 \mathrm{mg} \mathrm{pot}^{-1}$ or faba bean seeds in sandy clay loam soil and between 3.5 and $5.70 \mathrm{mg} \mathrm{pot}^{-1}$ for wheat grains and between 6.90 and $8.50 \mathrm{mg} \mathrm{pot}^{-1}$ for faba bean seeds in sandy soil. For the two tested plants grown in both soils, the lowest phosphorus uptake values of grains and seeds were found with the treatment of saw dust (SD), while the highest one was recorded with the treatments of chicken manure (CM). The roots phosphorus uptake values ranged between 1.31 and $2.16 \mathrm{mg}$ pot $^{-1}$ for wheat grains and between 1.68 and $3.5 \mathrm{mg} \mathrm{pot}^{-1}$ for faba bean seeds in a sandy clay loam soil and between 0.43 and $1.04 \mathrm{mg} \mathrm{pot}^{-1}$ for wheat grains 
and between 0.80 and $1.60 \mathrm{mg}^{-1}$ pot $^{-1}$ for faba bean seeds in the sandy soil. The lowest roots phosphorus uptake values were obtained under addition of the treatment of saw dust (SD) to the two tested plants in both soils, while the greatest ones were observed with the treatment of chicken manure $(\mathrm{CM})$ when applied to the two cultivated soils with both plants under study.

In general, the effect of organic soil amendments on the phosphorus uptake of straw, grains of wheat, seeds of faba bean and roots grown in both soils can be arranged for different treatments in the following descending order : $(\mathrm{CM})>($ FYM $)>($ Com $)>($ Bit $)>($ SD $)>($ Control $)$.

\section{Effect of Tested Organic Amendments on Potassium Uptake of Wheat and Faba Bean Plants Grown on the Investigated Soils}

The results given in Table 7 show the effect of organic amendments on straw, grains of wheat, seeds of faba bean and roots potassium uptake grown on sandy clay loam soil and sandy soil.

The results indicated that all the treatments in both soils, significantly increased the straw, seeds and roots potassium uptake compared to the control treatments. These findings are in harmony with those obtained by Kleinman et al. (2000), Bar-Tal et al. (2004), Jedidi et al. (2004) and Gil et al. (2007).

Irrespective of the control treatments, the straw potassium uptake values ranged between 12.6 and $20.7 \mathrm{mg} \mathrm{pot}^{-1}$ for wheat and between 9.4 and $16.4 \mathrm{mg} \mathrm{pot}^{-1}$ for faba bean in sandy clay loam soil and between 10.5 and $14.5 \mathrm{mg} \mathrm{pot}^{-1}$ for wheat and between 7.2 and $13.9 \mathrm{mg} \mathrm{pot}^{-1}$ for faba bean in sandy soil. The lowest straw potassium uptake values were observed with the treatment of saw dust (SD), while the greatest ones were obtained under the application of the treatment of chicken manure (CM) to the two tested soils under study. The values of grains and seeds potassium uptake ranged between 5.9 and $9.1 \mathrm{mg}$ pot $^{-1}$ for wheat grains and between 13.3 and $19.8 \mathrm{mg}^{-1}$ pot $^{-1}$ for faba bean seeds in sandy clay loam soil and between 4.3 and 8.5 $\mathrm{mg} \mathrm{pot}^{-1}$ for wheat grains and between 13.5 and $16.2 \mathrm{mg} \mathrm{pot}^{-1}$ for faba bean seeds in sandy soil, for the two tested plants grown in both soils.
The lowest potassium uptake values were found with the treatment of saw dust (SD), while the highest ones were recorded with the treatment of chicken manure $(\mathrm{CM})$.

The roots potassium uptake values ranged between 5.6 and $9.76 \mathrm{mg} \mathrm{pot}^{-1}$ for wheat and between 3.7 and $8.8 \mathrm{mg} \mathrm{pot}^{-1}$ for faba bean in a sandy clay loam soil and between 3.3 and 6.9 $\mathrm{mg} \mathrm{pot}^{-1}$ for wheat and between 3.4 and $7.3 \mathrm{mg}$ $\operatorname{pot}^{-1}$ for faba bean in a sandy soil The lowest potassium uptake weight values were obtained under addition of the treatment of saw dust (SD) to the two tested plants in both soils, while the greatest ones were observed with the treatment of chicken manure (CM) when applied to the two cultivated soils with both plants under study.

In general, the effect of soil organic amendments on the potassium uptake of straw, grains of wheat and seeds of faba bean, and roots grown in both soils can be arranged for different treatments in the following descending order: $(\mathrm{CM})>(\mathrm{FYM})>(\mathrm{Com})>(\mathrm{Bit})>(\mathrm{SD})>($ Control $)$.

\section{Effect of Tested Organic Amendments on Protein content $\left(\mathrm{g} \mathrm{kg}^{-1}\right)$ and Harvest Index (\%) of Wheat and Faba Bean Plants Grown on the Investigated Soils}

The results given in Table 8 show the effect of organic amendments on protein content in grains and seeds as well as harvest index of wheat and faba bean plants grown on sandy clay loam soil and sandy soil.

The results showed that all the treatments in both soils significantly increased the protein content in grains and seeds and harvest index compared to the control treatments. These findings are similar to those obtained by Sinjobi et al. (2010), Abd El-Rheem (2003) and Abdel All et al. (2003).

Irrespective of the control treatment, the protein content $\left(\mathrm{g} \mathrm{kg}^{-1}\right)$ in grains of wheat and seeds of faba bean values ranged between 60.4 and 70.9 for wheat and between 80.6 and 90.6 for faba bean in sandy clay loam soil and between 45.0 and 58.0 for wheat and between 78.1 and 86.3 for faba bean in sandy soil. The values of harvest index ranged between 50.8 and 57.4 for wheat and between 35.7 and 43.7 for faba bean in sandy clay loam soil and between 
Table 7. Effect of organic soil amendments on potassium uptake (mg $\left.\operatorname{pot}^{-1}\right)$ by wheat and faba bean plants grown on two different soils

\begin{tabular}{ccccccc}
\hline \multirow{2}{*}{ Treatment } & \multicolumn{3}{c}{ Sandy clay loam soil } & \multicolumn{3}{c}{ Sandy soil } \\
\cline { 2 - 6 } & Straw & Grains & Roots & Straw & Grains & Roots \\
\hline & & & Wheat & & & \\
Control & 9.60 & 3.60 & 1.90 & 5.80 & 2.90 & 1.50 \\
Bit & 15.2 & 6.30 & 5.90 & 12.2 & 4.80 & 3.60 \\
SD & 12.6 & 5.90 & 5.60 & 10.5 & 4.30 & 3.30 \\
FYM & 16.7 & 7.20 & 7.90 & 14.0 & 5.80 & 4.20 \\
CM & 20.7 & 9.10 & 9.76 & 14.5 & 8.50 & 6.90 \\
Com & 16.0 & 6.20 & 5.00 & 13.7 & 4.70 & 3.90 \\
LSD 0.05 & 0.2581 & 0.2315 & 0.2143 & 0.2463 & 0.2395 & 0.2475 \\
& & & Faba bean & & & \\
& Straw & Seeds & Roots & Straw & Seeds & Roots \\
Control & 6.30 & 11.4 & 2.200 & 4.70 & 10.7 & 1.70 \\
Bit & 10.8 & 13.8 & 4.10 & 9.70 & 13.5 & 3.90 \\
SD & 9.4 & 13.3 & 3.70 & 7.20 & 13.7 & 3.40 \\
FYM & 15.2 & 19.2 & 6.90 & 11.0 & 14.0 & 6.20 \\
CM & 16.4 & 19.8 & 8.80 & 13.9 & 16.2 & 7.30 \\
Com & 12.8 & 15.1 & 6.50 & 9.37 & 13.6 & 5.40 \\
LSD 0.05 & 0.2754 & 0.2155 & 0.2457 & 0.2149 & 0.2124 & 0.2658 \\
\hline
\end{tabular}

See footnote of Table 3 .

Table 8. Effect of organic soil amendments on protein content $\left(\mathrm{g} \mathrm{kg}^{-1}\right)$ and harvest index (\%) of wheat and faba bean plants grown on two different soils

\begin{tabular}{ccccc}
\hline Treatment & \multicolumn{2}{c}{ Sandy clay loam soil } & \multicolumn{2}{c}{ Sandy soil } \\
\cline { 2 - 5 } & Harvest index (\%) & Protein $\mathbf{( \mathbf { ~ k g } ^ { - 1 } )}$ & Harvest index (\%) & Protein $\mathbf{( \mathbf { g ~ k g } ^ { - 1 } )}$ \\
\hline & & Wheat plant & & \\
Control & 48.9 & 44.4 & 44.2 & 37.1 \\
Bit & 51.4 & 60.8 & 48.7 & 55.9 \\
SD & 50.8 & 60.4 & 47.1 & 45.0 \\
FYM & 56.4 & 63.1 & 50.2 & 57.0 \\
CM & 57.4 & 70.9 & 51.7 & 58.1 \\
Com & 53.4 & 62.2 & 50.1 & 57.0 \\
LSD 0.05 & 2.1352 & 0.4125 & 2.1542 & 0.2127 \\
& & Faba bean plant & & \\
Control & Harvest index (\%) & Protein (g kg-1) & Harvest index (\%) & Protein (g kg $\mathbf{- 1})$ \\
Bit & 28.4 & 62.5 & 18.9 & 52.5 \\
SD & 37.9 & 80.6 & 32.1 & 80.6 \\
FYM & 35.7 & 80.6 & 31.1 & 78.1 \\
CM & 43.4 & 88.6 & 34.7 & 81.3 \\
Com & 43.7 & 90.6 & 40.6 & 86.3 \\
LSD 0.05 & 42.9 & 83.8 & 33.6 & 81.9 \\
\hline S & 2.2183 & 0.7534 & 2.2093 & 0.5345 \\
\hline
\end{tabular}

See footnote of Table 3 . 
In general, the effect of organic amendments on the protein content and Harvest Index (\%) can be arranged for different treatments in the following descending order: $(\mathrm{CM})>(\mathrm{FYM})>$ $(\mathrm{Com})>(\mathrm{Bit})>(\mathrm{SD})>($ Control $)$

\section{REFERENCES}

Abdel Aal, S.I., A.M.A. Aal Hamid, S.A. Ismaiel, A. Abd El-Fattah and A.S. Tallab (2003). Effect of organic Farming practice on nutrient availability and wheat yield grown on torripsamments Egypt. J. Soil Sci., 43 (1): 47-62.

Abd-El-Rheem, K.M. (2003). Effect of natural soil amendments on fertilizer use efficiency as related to nutrient balance of plants grown on sandy soils. M.Sc. Thesis., Fac. Agric., Ain Shams Univ.

Ali, H.S.M. (2017). A preliminary study of some nutrients in different soils. M.Sc. Thesis, Fac. Agric., Zagazig Univ., Egypt.

Awad, H.A., S.A. Ismail and A.M. Abd-ElHafeez (2013). Effect of Nitrogen phosphorus and zinc fertilization on yield quality and nutrients of berseem. Barley mixture. Fayoum. J. Agric. Res. and Dev., 26 (2): 30-44.

Bar-Tal, A., U. Yermiyahu, J. Beraud, M. Keinan, R. Rosenberg, D. Zohar, V. Rosen and P. Fine (2004). Nitrogen, phosphorus, and potassium uptake by wheat and their distribution in soil following successive, annual compost applications. J. Environ. Qual., 33: 1855-1865.

Basyouny, E.A. (2001). Plant response to fertilization in relation to micronutrients status in plant and soil Ph.D. Thesis, Fac. Agric., Ain Shams Univ., Egypt.

Basyouny, E.A. (2002). Significance of applied organic manuring in some newly reclaimed areas under different water qualities. Fayoum J. Agric., Res. Dev., 16 (2):163-201.

Basyouny, E.A., Sh. El-Borhamy and S.A. Eisa (2003). Response of corn plants grown on calcareous soil to organic fertilization and sulphur. Egypt. J. Appl. Sci., 18 (9):360-372.
Bishni, U.R. and I.L. Hughes (1979). Agronomic performance and protein content of fall-planted tritica, wheat and rye. Agron. J., $71: 359-360$.

Black, C.A., D.D. Evans, J.L. White, L.E. Ensminger and F.E. Chark (1965). Methods of Soil Analysis". Part. Z. Agron. Ame. Soc. Agron. Inc. Modison Wisc.

Chapman, D.H. and P.F. Pratt (1961). Methods of analysis for soil, plant and waters". Calif. Univ., Div. Agric. Sci.

Chen, H.J. (2006). The combined use of chemical and organic fertilizers and/or bio fertilizer for crop growth and soil fertility. Dept. of soil and environ. Sci., Nat. Chung Hsing Univ., 3-4.

Chirevnje, T. and L.Q. Ma (2002). Impact of high volume wood-fired boiler ash amendment status. Comm. Soil Sci. Plant Anal., 33 : 1-18.

Cooperband, L., G. Bollero and F. Coale (2002). Effect of poultry litter and composts on soil nitrogen and phosphorus availability and corn production. Nutr. Cycl. Agroecosys, 62: 185-194.

Courtney, R.G. and G.J. Mullen (2007). Soil quality and barley growth as influenced by the land application of two compost types. Biores. Technol., doi:10.1016/ J. Biortech. 2007. 06.034

El-Kohly, H.E.M., T.A. Abou El-Defan and M.M. El-Ghanam (2000). Influence of some natural soil conditioners on wheat grown on sandy soils. J. Agric. Sci., Mansoura Univ., 25 (91): 5963-5971.

El-Sayed, N.M.M. (2017). Effect of some organic sources on soil phosphorus availability and plant growth soil. Ph.D. Thesis, Fac. Agric. Zagazig Univ., Egypt.

El-Tahawy, A.M.A. (2017). Phosphorus Bio Availability in soils M.Sc. Thesis. Fac. Agric., Zagazig Univ., Egypt.

El-Zahar, H., I.H. El-Sokkary and A.E. Abd ElAll, (2007). Effect of sewage sludge application on the properties of cultivated calcareous soil. 2-soil physical properties and 
trace elements contents in wheat and corn plants conf. Hall, Fac. Agric., Mansoura Univ., 161-169.

Gil, M.V., M.T. Carballo and L.F. Calvo (2007). Fertilization of maize with compost from cattle manure supplemented with additional mineral nutrients. Waste Manag., doi: 10.1016/ j.wasman.2007.05.009

Hassan, M.A.M., R.K. Rabie and E.R. Marzouk (2002). Effect of some combination of organic wastes and biofertilizer on phosphorus availability in certain soils in North Sinai. Zagazig J. Agric. Res., 29

Hassanien., A.A., N.G.M. Aziz and A.A.A. Wahdan (2007). Expected utilization of applying some local soil organic and inorganic amendments for optimizing tomato fruit yield of high quality in sandy soil. Egypt. J. Appl. Sci., 19 (5B): 611-622.

Jackson, M.L. (1972). Soil Chemical Analysis. Prentice Hall, Ic. Englewood cliffs, New Jersey.

Jackson, M.L. (1973). Soil Chemical Analysis. Prentice Hall, Ic. Englewood cliffs, New Jersey.

Jedidi, N., A. Hassen, O. Van Cleemput and A. M'Hiri (2004). Microbial biomass in a soil amended with different types of organic wastes. Waste Manag. Res., 22: 93-99.

Kleinman, P.J.A., R.B. Bryant, W.S. Reid, A.N. Sharpley and D. Pimentel (2000). Using soil $\mathrm{P}$ behavior to identify environmental thresholds. Soil Sci., 165: 943-950.

Merwad, A.M.A. (2009). Effect of some soil amendments on behavior of some nutrients in different soils M.Sc. Thesis, Fac. Agric. Zagazig Univ., Egypt.

Merwad A.M.A (2013).Efficiency of phosphate fertilizers as influenced by soil amendments application in soil. Ph.D. Thesis, Fac. Agric., Zagazig Univ., Egypt.
Rochette, P., A.A. Denis, H.C. Martin, G. Bernard and B. Normand (2006). In situ Mineralization of Dairy Cattle Manures as Determined using Soil-Surface Carbon Dioxide Fluxes. Soil Sci. Soc. Ame. J. Madison, USA, 70: 744-752.

Rus, A.I., L.B. Yakubov and D. Dslt (2005). Mapping the Arabidosis Ionome". Proceeding: $15^{\text {th }}$ Int. Plant Nutr. Colloquium Food Sec. Human Health and Environ. Prot. Beijing.China, 20-24 Aug., 2-5.

Senjobi, B., O. Ande, C. Senjobi, O. Odusanya and O. Ajilore (2010). Effects of organic amendments on the growth and performance of Celosia argentea on an oxic Paleustalf in South western Nigeria. J. Agric. Biotech. and Sustain. Dev., 2(8): 142-150.

Shnsuke, A. (2004). Effect of nitrogen availability from organic nitrogen sources M.Sc. Thesis Michigan State Univ.

Taha, M.B. (2000). Effect of using some organic amendments for improving the productivity of coarse textured soils. M.Sc. Thesis, Fac. Agric., Minia Univ., Egypt.

Telep, A.M. (2008). Application effect of some organic amendments on the availability of phosphorus and fodder grass yield in a sandy loam soil. Minia. J. Agric. Res., 28 (3): 429447.

Watanabe, F.S. and S.R. Olsen (1965). Test of ascorbic acid method for determing phosphorus in water and $\mathrm{NaHCO}_{3}$ extracts from soil. Soil Sci. Soc. Amer. Proc., 29 : $677-678$.

Zhang, A., L. He, H. Zhao and Z. Wu (2009). Effect of organic acids on inorganic phosphorus transformation in soil with different phosphorus sources. China J. Appl. Environ. Biol., 15 (4): 474- 478.

Zhuo, A., L. He and H. Zhao (2009). Effect of organic acids on inorganic phosphorus transformation in soils and its readily available phosphate. Acta Ecol. Sinica. 29 (8): 4061-4069. 
تأثير بعض المواد العضوية على إنتاجية محصولي القمح والفول البلاي المزروعة في ارضين مختلفتين

$$
\begin{aligned}
& \text { إسلام عصام ابراهيم محمد الجابري- ابراهيم رمضان محمد- أيمن محمود حلمي - سامح محمد شداد }
\end{aligned}
$$

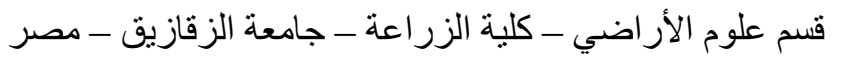

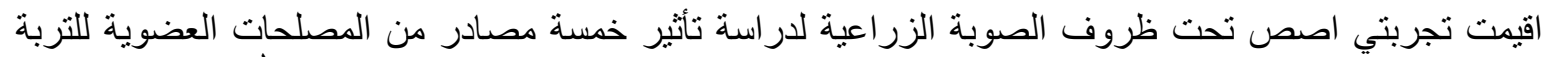

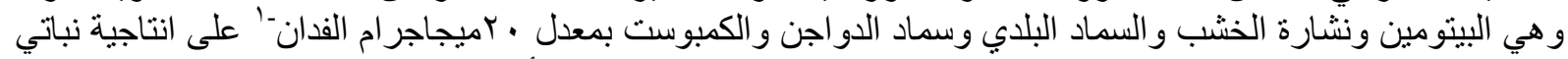

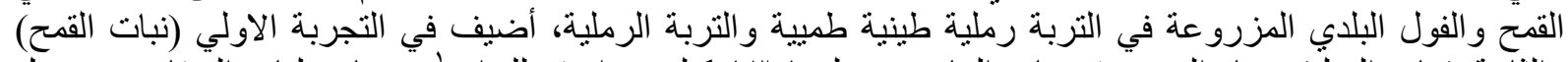

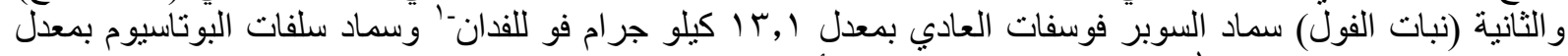

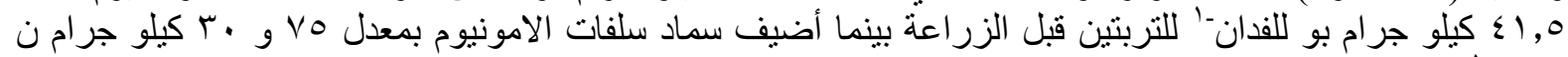

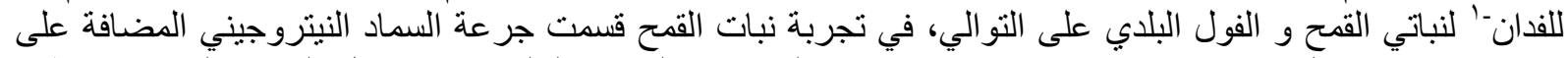

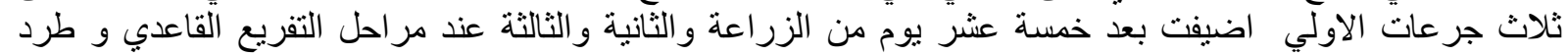

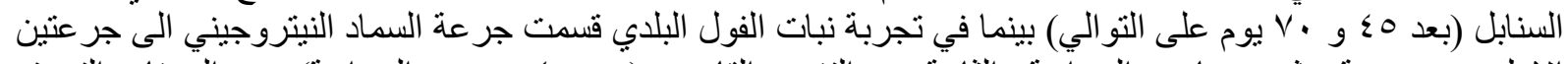

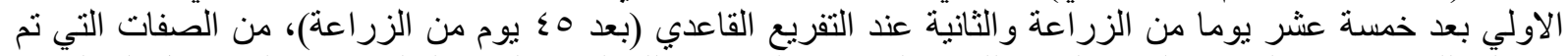

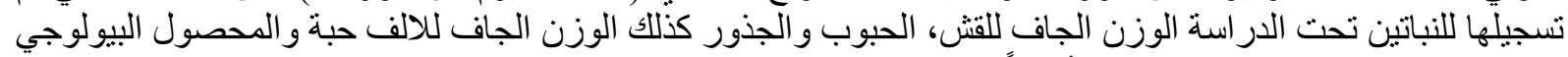

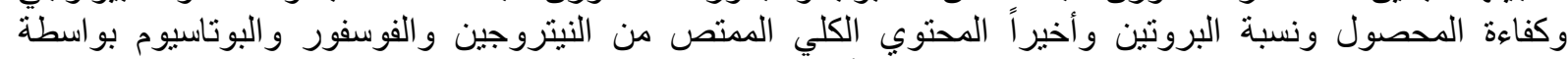

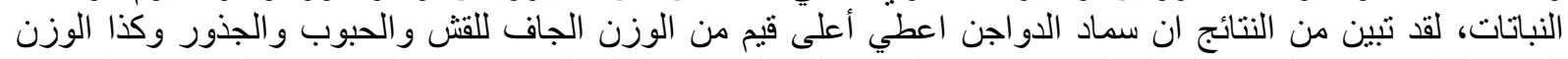

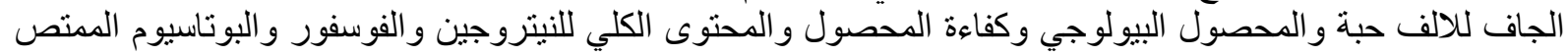

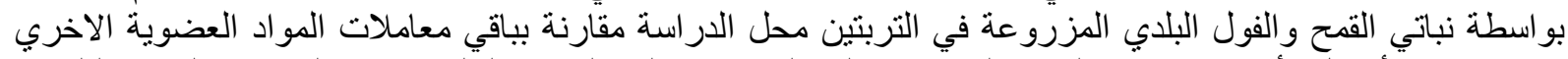

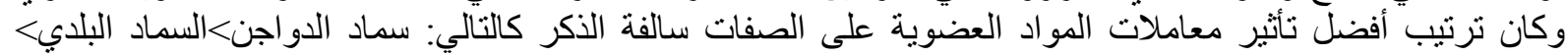
الكمبوست>البيتومين>نشارة الخشب> التربة غير المعاد المعلة. 